\title{
GROWTH AND YIELD PERFORMANCE OF TIDAL LOCAL AMAN RICE AS INFLUENCED BY USG APPLICATION AT NON TIDAL CONDITION
}

\author{
S. M. S. Abedin ${ }^{1}$, M. A. Mannan ${ }^{1}$, M. A. A. Mamun ${ }^{1,}$, , G. K. M. M. Rahman ${ }^{1}$ and A. J. Mridha ${ }^{2}$ \\ 1Bangabandhu Sheikh Mujibur Rahman Agricultural University, Gazipur-1706 \\ 2Bangladesh Rice Research Institute, Gazipur-1701 \\ "Corresponding author: aamamunbrri@yahoo.com
}

Key words: grain yield, local aman, tidal area, urea super granule

\begin{abstract}
An experiment was carried out at research field of Bangladesh Rice Research Institute, Gazipur to evaluate the performance of tidal local aman rice as influenced by urea super granule (USG) at non-tidal condition. Four tidal local aman varieties such as Sadamota, Razashail, Kutiagoni and Kalagura were used as planting materials. Nitrogen was applied as USG $(1.8 \mathrm{~g})$ at 10 days after transplanting (DAT), 25 DAT, before panicle initiation (BPI) stage (date of PI stage of these 4 varieties were identified from previous experience) and no nitrogen (control). The experiment was laid out in a splitplot design where varieties in main plot and USG in sub-plot with three replications. Varietals response was significant on plant height, effective tillers hill ${ }^{-1}$, grains panicle $e^{-1}$ and grain yield. All the yield and yield components were influenced significantly by the time of USG application. Higher dry matter was produced by all the varieties when USG was applied at early growth stage (10 to 25 DAT) but crop lodges at milking stage due to more vegetative growth resulting increases sterility, decreases grain fertility and yield. On the other hand, when USG was applied at BPI stage grain fertility and yield were increased. The highest grain yield $\left(3.51 \mathrm{t} \mathrm{ha}^{-1}\right)$ was recorded from Kalagura when USG applied before panicle initiation stage. So, application of USG at BPI stage in local aman rice in non-tidal condition increased yield resulting higher gross and net return in all varieties.
\end{abstract}

\section{Introduction}

Sustainable rice production is a great challenge for the rice grower under climate change condition. Low productive tidal submergence ecosystem is one of the major unfavorable agroecological situations in Bangladesh (Hossain et al., 2002). More than 1.0 million ha of greater Barisal and Patuakhali districts are inundated up to the range of 6-90 $\mathrm{cm}$ for about 4-5 months from June to October (BRRI, 2004). Aman season (June to November) is one of the major crops growing seasons and farmers cultivate local varieties. High yielding varieties cannot survive under tidal ecosystem. Locally popular traditional varieties like Lothor, Lalpyka, Kutiagoni, Mutha, Razashail, Sada pajam, Lal chikon, Sada chikon Sada muta, Lal muta and Moulata etc. are resistant and perform better in tidal areas. Due to tidal water movement, farmers do not apply fertilizer in aman season. It is often impossible to follow recommended practices of nutrient management like nitrogen $(\mathrm{N})$ fertilizer because there is a high risk of surface $\mathrm{N}$ losses to tidal water. So, the yield of cultivated local rice varieties is low and it is because of low $\mathrm{N}$ concentration in the leaf canopy during grain filling period, early senescence of leaves and low rates of photosynthesis (Cassman et al., 1995). The increase in amount of $\mathrm{N}$ at the booting stage may provide sufficient $\mathrm{N}$ to rice plants during the late filling stage. High plant $\mathrm{N}$ content delays leaf senescence and therefore increases photosynthetic duration (Makino, 
Abedin et al.

2011). The application of $\mathrm{N}$ fertilizer has been reported to have a great effect on filling of grain (Juan et al., 2006). It has been reported that the amount and time of nitrogen application had tremendous effects on filling and dry matter accumulation in rice (Mnzava, 2002). Moreover, nitrogen application at PI stage through deep placement of USG (UDP) may escape vegetative growth and this may increase the number of grains panicle ${ }^{-1}$ and better grain filling. Increased application of $\mathrm{N}$ fertilizer at flowering stage found to increase the yield of rice (Cassman et al., 1994). Usually, urea super granule (USG) is placed to the rice field at 8-10 days after transplanting that helps to vigorous vegetative growth (Ranjith et al., 2008). Little research has been done on USG deep placement in local rice varieties in tidal areas of Bangladesh. Under the above circumstances, the study was undertaken to evaluate the performance of local aman rice varieties in respect of yield and nitrogen use efficiency and to find out suitable time of nitrogen application in local aman rice in agro-climate condition of Gazipur.

\section{Materials and methods}

The experiment was carried out at Agronomy field of Bangladesh Rice Research Institute, Gazipur during the Aman season, 2014. The soil of BRRI farm was clay loam of shallow brown terrace under Madhupur tract (AEZ 28), with pH 6.2 and low in organic matter (1.2\%). The experimental field was ploughed with the help of power tiller followed by laddering to get a well puddled condition. A blanket dose of $16,35,10$ and $1.8 \mathrm{~kg} \mathrm{ha}^{-1}$ of $\mathrm{P}, \mathrm{K}, \mathrm{S}$ and $\mathrm{Zn}$ were applied as triple super phosphate, muriate of potash, gypsum and zinc sulphate, respectively at final land preparation. The treatments were, Factor A: Local aman varieties, i. Sadamota, ii. Razashail, iii. Kutiagoni and iv. Kalagura; Factor B: Time of USG (1.8g) application at i. 10 DAT, ii. 25DAT, iii. Before Panicle Initiation (BPI) stage and iv. No nitrogen (control). The experiment was laid out in split-plot design assisning varieties in main plot and USG in sub-plot with three replications. Thirty-days-old seedlings were transplanted maintaining $30 \mathrm{~cm} \times 30 \mathrm{~cm}$ spacing on $7^{\text {th }}$ August, 2014. Intercultural operation like gap filling was done on $15^{\text {th }}$ August, 2014. Two hand weeding was done on $22^{\text {nd }}$ August and $10^{\text {th }}$ September, 2014. Irrigation water was applied as and when necessary. Data on tillering dynamics, SPAD value, dry matter production, yield and yield components were recorded following standard procedure. Grain yield was adjusted to $14 \%$ moisture content. Agronomic efficiency, partial factor productivity and grain yield efficiency index were calculated using following formulae.

i. Agronomic efficiency (AE)

$\mathrm{AE}_{\mathrm{N}}=\left(\mathrm{GY}_{+\mathrm{N}}-\mathrm{GY}_{0 \mathrm{~N}}\right) / \mathrm{FN}$

Where, $\mathrm{AE}_{\mathrm{N}}=$ Agronomic efficiency of $\mathrm{N} ; \mathrm{GY}_{+\mathrm{N}}=$ Grain yield due to addition of $\mathrm{FN}$; $\mathrm{GY}_{0}$ $\mathrm{N}=$ Grain yield without addition of $\mathrm{N} ; \mathrm{FN}=$ Amount of $\mathrm{N}$ applied $\left(\mathrm{kg} \mathrm{ha}^{-1}\right)$.

ii. Partial factor productivity (PFP)

$\mathrm{PFP}_{\mathrm{N}}=\mathrm{GY}_{+\mathrm{N}} / \mathrm{FN}$

Where, $\mathrm{PFP}_{\mathrm{N}}=$ Partial factor productivity of $\mathrm{N} ; \mathrm{GY}_{+\mathrm{N}}=$ Grain yield due to addition of FN; $\mathrm{FN}=$ Amount of $\mathrm{N}$ applied $\left(\mathrm{kg} \mathrm{ha}^{-1}\right)$.

iii. Grain yield efficiency index (GYEI)

$$
\text { GYEI }=\frac{\text { Grain yield in N applied plot }}{\text { Average grain yield for all varieties in N applied plot }} \times \frac{\text { Grain yield in control plot }}{\text { Average grain yield for all varieties in control plot }}
$$

Data gathered on different parameters were statistically analyzed and the mean different among the treatments were compared by least significance difference (LSD) test at 5\% level of significance. 
Growth and Yield Performance of Tidal Local Aman Rice by USG

\section{Results and Discussion}

Tiller production (no. hill-1)

Tiller production varied in cultivated varieties due to USG application at different times (Table 1). In general, the number of tillers per hill increases with the advance of time upto certain period.

Maximum number of tillers was recorded at 40 to 60 DAT from almost all the studying varieties irrespective of time of USG application. The lowest number of tillers was recorded with var. Kalagura from control plot and the highest from var. Razashail when USG was applied at BPI at 20 DAT of crop. At 40 DAT, there was no significant difference among the varieties in case of tiller production. At 60 DAT, the highest number of tillers per hill was recorded when USG applied at BPI in var. Kalagura. At 80 DAT, highest number of tillers was found from var. Sada mota and Kutiagoni when USG applied at BPI. At 80 DAT, the lowest number of tillers was recorded from the var. Razashail when USG applied at early crop growth stage (10 DAT). Number of tillers per hill is most important component of yield. The decrease in tiller number was attributed to the death of some tillers as a result of their failure in competition for light and nutrients (Fageria et al., 1997). More number of tillers might be due to the more availability of nitrogen that played a vital role in cell division.

Table 1. Variation of tiller/hill production due to interaction of variety and time of USG application at different days after transplanting (DAT) of rice

\begin{tabular}{|c|c|c|c|c|}
\hline \multirow{2}{*}{ Time of USG Application } & \multicolumn{4}{|c|}{ Variety } \\
\hline & Sada mota & Razashail & Kutiagoni & Kalagura \\
\hline & \multicolumn{4}{|c|}{20 DAT } \\
\hline $10 \mathrm{DAT}$ & 6 & 7 & 7 & 6 \\
\hline $25 \mathrm{DAT}$ & 6 & 6 & 7 & 6 \\
\hline BPI & 7 & 8 & 6 & 7 \\
\hline Control & 6 & 7 & 7 & 5 \\
\hline LSD (0.05) & \multicolumn{4}{|c|}{$\begin{array}{l}\text { NS } \\
16.3\end{array}$} \\
\hline CV (\%) & \multirow{2}{*}{\multicolumn{4}{|c|}{$\frac{16.3}{40 \text { DAT }}$}} \\
\hline & & & & \\
\hline $10 \mathrm{DAT}$ & 20 & 20 & 19 & 19 \\
\hline $25 \mathrm{DAT}$ & 19 & 20 & 20 & 19 \\
\hline BPI & 21 & 21 & 21 & 21 \\
\hline Control & 18 & 19 & 19 & 18 \\
\hline LSD (0.05) & \multirow{2}{*}{\multicolumn{4}{|c|}{$\begin{array}{c}\text { NS } \\
13.2\end{array}$}} \\
\hline CV (\%) & & & & \\
\hline & \multicolumn{4}{|c|}{60 DAT } \\
\hline $10 \mathrm{DAT}$ & 18 & 20 & 17 & 21 \\
\hline 25 DAT & 20 & 21 & 19 & 22 \\
\hline BPI & 21 & 22 & 20 & 23 \\
\hline Control & 19 & 19 & 16 & 18 \\
\hline $\operatorname{LSD}(0.05)$ & \multirow{2}{*}{\multicolumn{4}{|c|}{$\begin{array}{c}\text { NS } \\
12.6\end{array}$}} \\
\hline $\mathrm{CV}(\%)$ & & & & \\
\hline & \multicolumn{4}{|c|}{80 DAT } \\
\hline 10 DAT & 16 & 15 & 17 & 17 \\
\hline 25 DAT & 20 & 17 & 20 & 19 \\
\hline BPI & 21 & 19 & 21 & 20 \\
\hline Cont & 14 & 16 & 16 & 15 \\
\hline LSD (0.05) & \multirow{2}{*}{\multicolumn{4}{|c|}{$\begin{array}{c}\text { NS } \\
15.7\end{array}$}} \\
\hline $\mathrm{CV}(\%)$ & & & & \\
\hline
\end{tabular}

$\mathrm{BPI}=$ Before panicle initiation stage 
Abedin et al.

\section{SPAD values}

The interaction effect of variety and time of USG application on SPAD value was not significant at 20 DAT (Table 2). The highest SPAD value was recorded with var. Razashail during application of USG at BPI stage and lowest from Kalagura when USG applied during 10 DAT and 20 DAT of rice. At 40 DAT, the highest SPAD value (43.23) was demonstrated from Kalagura from USG application at 10 DAT. The interaction between the variety and the time of USG application was not significant at 40 and 80 DAT. At 60 DAT, the highest SPAD value (43.33) was recorded from Kalagura with USG application at 25 DAT and the lowest (32.93) from the control plot with Sada mota when USG applied at 10 DAT. The var. Sada mota gave the lowest SPAD value and the highest SPAD value from Kalagura when USG applied at 25 DAT and 80 DAT. Hassan et al. (2009) reported that SPAD value and nitrogen content showed significant differences under variable nutrient levels and time of urea application.

Table 2. Variation of SPAD values due to interaction of variety and time of USG application at different days after transplanting (DAT) of rice

\begin{tabular}{|c|c|c|c|c|}
\hline \multirow{2}{*}{ Time of USG Application } & \multicolumn{4}{|c|}{ Variety } \\
\hline & Sada mota & Razashail & Kutiagoni & Kalagura \\
\hline & \multicolumn{4}{|c|}{20 DAT } \\
\hline 10 DAT & 36.40 & 36.19 & 35.56 & 32.53 \\
\hline 25 DAT & 34.95 & 34.21 & 35.26 & 34.13 \\
\hline BPI & 35.94 & 36.76 & 36.86 & 34.20 \\
\hline Control & 35.08 & 35.14 & 36.16 & 33.60 \\
\hline LSD (0.05) & \multicolumn{4}{|c|}{ NS } \\
\hline CV $(\%)$ & \multicolumn{4}{|c|}{4.8} \\
\hline & \multicolumn{4}{|c|}{40 DAT } \\
\hline 10 DAT & 39.30 & 40.87 & 39.73 & 43.23 \\
\hline 25 DAT & 40.33 & 42.17 & 39.67 & 42.27 \\
\hline BPI & 38.67 & 40.20 & 43.20 & 40.33 \\
\hline Control & 39.93 & 40.90 & 41.83 & 39.67 \\
\hline $\mathrm{LSD}_{0.05}$ & \multicolumn{4}{|c|}{$\begin{array}{l}\text { NS } \\
70\end{array}$} \\
\hline $\mathrm{CV}(\%)$ & & & & \\
\hline & \multicolumn{4}{|c|}{60 DAT } \\
\hline 10 DAT & 36.73 & 37.23 & 35.67 & 35.63 \\
\hline 25 DAT & 34.43 & 36.73 & 36.70 & 37.33 \\
\hline BPI & 36.83 & 34.80 & 35.03 & 35.67 \\
\hline Control & 32.93 & 35.10 & 34.23 & 34.80 \\
\hline LSD (0.05) & \multicolumn{4}{|c|}{$\begin{array}{c}2.74 \\
4.6\end{array}$} \\
\hline $\mathrm{CV}(\%)$ & & & & \\
\hline & \multicolumn{4}{|c|}{80 DAT } \\
\hline 10 DAT & 33.23 & 33.40 & 33.67 & 36.50 \\
\hline $25 \mathrm{DAT}$ & 31.13 & 31.97 & 33.53 & 39.30 \\
\hline BPI & 33.90 & 32.13 & 36.77 & 36.93 \\
\hline Control & 34.20 & 31.33 & 35.23 & 36.40 \\
\hline LSD (0.05) & \multirow{2}{*}{\multicolumn{4}{|c|}{$\begin{array}{l}\text { NS } \\
7.1\end{array}$}} \\
\hline CV (\%) & & & & \\
\hline
\end{tabular}

$\mathrm{BPI}=$ Before panicle initiation stage

\section{Dry matter production at flowering stage $\left(\mathrm{g} \mathrm{m}^{-2}\right)$}

The interaction between variety and time of USG application was not significant statistically for dry matter production DAT (Table 3). Application of USG at 25 DAT produced higher leaf blade dry matter in Kalagure $\left(230.96 \mathrm{~g} \mathrm{~m}^{-2}\right.$ ) followed by Sada mota (228.85 $\left.\mathrm{g} \mathrm{m}^{-2}\right)$. The lowest 
Growth and Yield Performance of Tidal Local Aman Rice by USG

dry matter was obtained from Razsahil when USG applied at 10 DAT. On the other hand, Sada mota gave maximum leaf sheath dry matter (256. $52 \mathrm{~g} \mathrm{~m}^{-2}$ ) when USG applied at 25 DAT. Stem dry matter was maximum in Kalagura in USG application at 25 DAT and BPI stage. The var. Kutiagoni produced maximum panicle dry matter when USG applied at 25 DAT. The total dry matter was maximum when USG applied at 25 DAT in Kalagura $\left(833.61 \mathrm{~g} \mathrm{~m}^{-1}\right)$ followed by Sada mota $\left(826.90 \mathrm{~g} \mathrm{~m}^{-1}\right)$ (Table 3). The lowest dry matter was obtained from Razashail in control plot. Crop attributes such as leaf area index and shoot dry matter were dependent on the applied nitrogen level applied and time of application. The higher growth resulting from increased nitrogen application could be attributed to the effects of nitrogen on cell division and elongation, synthesis of amino acids as well as its impact on some physiological processes favoring growth. Dry matter production exhibited a greater response to late-season application of N (Fageria and Baligar, 2001).

Table 3. Interaction of variety and time of USG application on dry matter production $\left(\mathrm{g} \mathrm{m}^{-2}\right)$ at flowering stage

\begin{tabular}{|c|c|c|c|c|}
\hline \multirow{3}{*}{ Time of USG application } & \multicolumn{4}{|c|}{ Variety } \\
\hline & \multicolumn{4}{|c|}{ Dry matter $\left(\mathrm{g} \mathrm{m}^{-2}\right)$} \\
\hline & Sada mota & Razashail & Kutiagoni & Kalagura \\
\hline & \multicolumn{4}{|c|}{ Leaf blade } \\
\hline 10 DAT & 186.77 & 86.11 & 181.15 & 205.10 \\
\hline $25 \mathrm{DAT}$ & 228.85 & 113.80 & 108.85 & 230.96 \\
\hline BPI & 162.73 & 92.57 & 126.23 & 221.23 \\
\hline Control & 159.82 & 99.50 & 104.68 & 180.59 \\
\hline LSD (0.05) & \multirow{2}{*}{\multicolumn{4}{|c|}{$\begin{array}{c}\text { NS } \\
21.2\end{array}$}} \\
\hline CV (\%) & & & & \\
\hline & \multicolumn{4}{|c|}{ Leaf sheath } \\
\hline 10 DAT & 205.70 & 77.82 & 140.48 & 236.03 \\
\hline 25 DAT & 256.52 & 72.64 & 158.38 & 223.31 \\
\hline BPI & 203.12 & 91.15 & 133.03 & 224.36 \\
\hline Control & 171.01 & 82.65 & 112.36 & 199.88 \\
\hline LSD (0.05) & \multirow{2}{*}{\multicolumn{4}{|c|}{$\begin{array}{c}\text { NS } \\
25.2\end{array}$}} \\
\hline CV (\%) & & & & \\
\hline & \multicolumn{4}{|c|}{ Stem } \\
\hline 10 DAT & 178.92 & 135.88 & 187.86 & 219.47 \\
\hline 25 DAT & 221.60 & 199.14 & 177.46 & 271.68 \\
\hline BPI & 218.24 & 150.52 & 143.14 & 271.86 \\
\hline Control & 151.51 & 129.75 & 136.48 & 220.63 \\
\hline $\operatorname{LSD}(0.05)$ & \multirow{2}{*}{\multicolumn{4}{|c|}{$\begin{array}{c}\text { NS } \\
20.5\end{array}$}} \\
\hline CV (\%) & & & & \\
\hline & \multicolumn{4}{|c|}{ Panicles } \\
\hline 10 DAT & 102.65 & 95.85 & 141.62 & 116.75 \\
\hline 25 DAT & 146.93 & 117.79 & 180.23 & 107.64 \\
\hline BPI & 136.23 & 118.96 & 197.58 & 113.50 \\
\hline Control & 129.23 & 83.324 & 155.10 & 115.11 \\
\hline LSD (0.05) & \multirow{2}{*}{\multicolumn{4}{|c|}{$\begin{array}{c}\text { NS } \\
18.7\end{array}$}} \\
\hline CV $(\%)$ & & & & \\
\hline & \multicolumn{4}{|c|}{ Total } \\
\hline 10 DAT & 674.06 & 395.66 & 669.38 & 777.37 \\
\hline 25 DAT & 826.90 & 503.38 & 677.32 & 833.61 \\
\hline BPI & 754.96 & 453.21 & 606.50 & 790.96 \\
\hline Control & 611.28 & 395.13 & 509.55 & 716.23 \\
\hline $\operatorname{LSD}(0.05)$ & \multirow{2}{*}{\multicolumn{4}{|c|}{$\begin{array}{c}\text { NS } \\
15.4\end{array}$}} \\
\hline $\mathrm{CV}(\%)$ & & & & \\
\hline
\end{tabular}

$\mathrm{BPI}=$ Before panicle initiation stage 
Abedin et al.

\section{Crop lodging at milking stage}

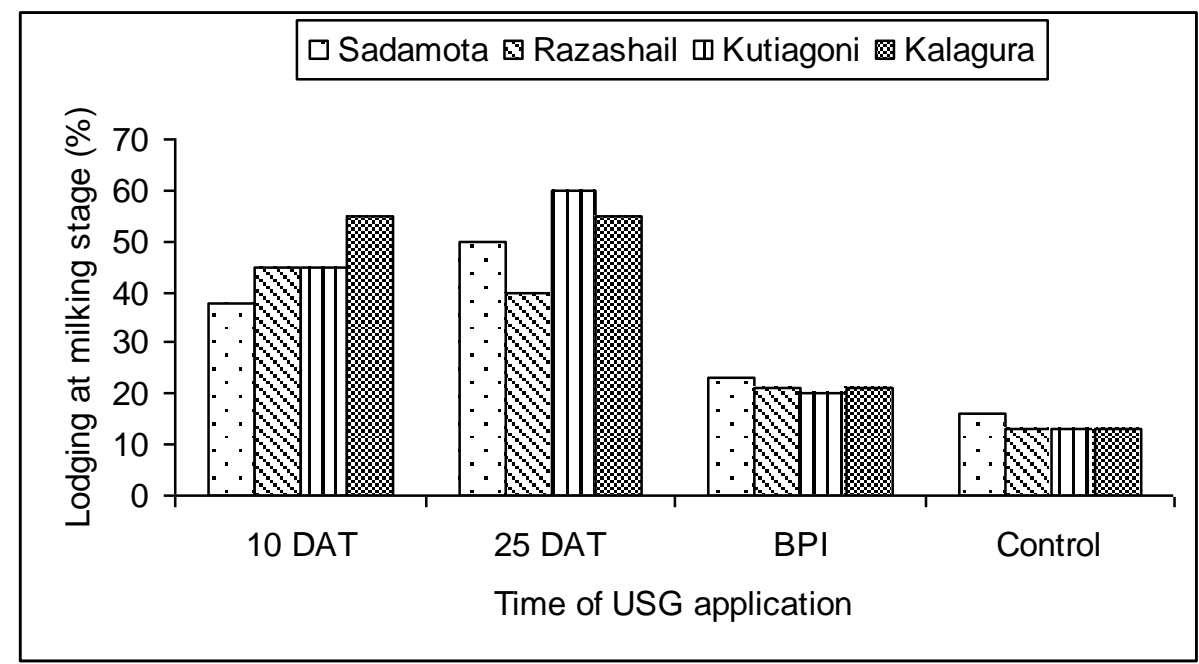

Fig. 1. Variation of crop lodging at milking stage due to interaction of variety and time of USG application

All varieties were lodged at milking stage. The lodging was the maximum when USG applied at 10 and 25 DAT but more than $40 \%$ plant lodged at 10 and 25 DAT but less than $20 \%$ plant lodged when USG applied at BPI stage (Fig. 1).

\section{Yield and yield contributing characters}

Variation of 1000 - grain weight, grains panicle $e^{-1}$, panicle $\mathrm{m}^{-2}$, grain yield was not statistically significant (Table 4) due to interaction of variety and time of USG application. Numerically, 25 DAT of Sada mota gave the highest 1000-grain weight (33.20g) followed by the BPI of Sada mota (32.29) whereas lowest from the control plot of var. Kutiagoni. The number of grains per panicle varied from 83 to 135 where maximum number of grains per panicle (135) was found from Kutiagoni at 10 DAT followed by Kutiagoni at BPI but var. Kalagura and 10 DAT combinations showed the least number of grains per panicle (83). The maximum number of panicle per $\mathrm{m}^{-2}$ (201) was recorded from Kalagura at 10 DAT followed by Kalagura 25 DAT (193) whereas lowest from control plot of var. Kutiagoni (112). The number of panicles per unit area depends on environmental conditions during tiller bud initiation and subsequent development stages. Grain yield varied from 2.23 to $4.02 \mathrm{t} \mathrm{ha}^{-1}$ where BPI of var. Kalagura gave the maximum yield (4.02 $\mathrm{t} \mathrm{ha}^{-1}$ ) followed by BPI of Sada mota (3.90 $\left.\mathrm{t} \mathrm{ha}^{-1}\right)$. Control plot of Razashail yielded the lowest grain yield $\left(2.23 \mathrm{t} \mathrm{ha}^{-1}\right)$. The variation in grain yield with nitrogen fertilization varied from 66 to 93\% depending on genotypes (Fageria et al., 2004). It was found that application of nitrogen improves various crop parameters like 1000- grain weight, more productive tillers and grain yield thus resulting in higher yields (Chaturvedi, 2005).

\section{Agronomic efficiency}

Agronomic efficiency was significantly varied due to interaction of variety and time of USG application (Table 5). Agronomic efficiency varied from 20.88 to 49.75. The maximum agronomic efficiency (49.75) was recorded from Kalagura during BPI stage followed by agronomic efficiency (44.03) Kutiagoni at BPI while the lowest agronomic efficiency (20.88) 
Growth and Yield Performance of Tidal Local Aman Rice by USG

from Sada mota during 10 DAT (Table 5). Agronomic efficiency in low land rice in the tropics to be in the range of 15 to $25 \mathrm{~kg}$ grain produced per $\mathrm{kg}$ of applied $\mathrm{N}$ (Yoshida, 1981).

Table 4. Interaction of variety and time of USG application on yield and yield components of rice

\begin{tabular}{|c|c|c|c|c|}
\hline \multirow[t]{3}{*}{ Time of USG Application } & \multicolumn{4}{|c|}{ Variety } \\
\hline & \multicolumn{4}{|c|}{ 1000-grain weight (g) } \\
\hline & Sada mota & Razashail & Kutiagoni & Kalagura \\
\hline 10 DAT & 29.58 & 25.83 & 26.71 & 30.35 \\
\hline 25 DAT & 33.20 & 24.17 & 29.28 & 27.23 \\
\hline BPI & 32.29 & 26.36 & 27.51 & 27.27 \\
\hline Control & 30.40 & 25.04 & 23.75 & 26.20 \\
\hline $\operatorname{LSD}(0.05)$ & \\
\hline \multirow[t]{2}{*}{ CV (\%) } & \multicolumn{4}{|c|}{9.2} \\
\hline & \multicolumn{4}{|c|}{ No of grains panicle $e^{-1}$} \\
\hline 10 DAT & 105 & 97 & 135 & 83 \\
\hline 25 DAT & 96 & 86 & 102 & 97 \\
\hline BPI & 113 & 91 & 126 & 117 \\
\hline Control & 95 & 85 & 106 & 94 \\
\hline LSD (0.05) & \\
\hline \multirow{2}{*}{$\mathrm{CV}(\%)$} & \multicolumn{4}{|c|}{15.3} \\
\hline & \multicolumn{4}{|c|}{ No of panicle $\mathrm{m}^{-2}$} \\
\hline 10 DAT & 129 & 182 & 148 & 201 \\
\hline 25 DAT & 142 & 175 & 163 & 193 \\
\hline BPI & 152 & 150 & 154 & 190 \\
\hline Control & 125 & 125 & 112 & 140 \\
\hline LSD (0.05) & \\
\hline \multirow[t]{2}{*}{ CV $(\%)$} & \multirow{2}{*}{\multicolumn{4}{|c|}{$\begin{array}{l}12.7 \\
\text { Grain yield }\left(\mathrm{t} \mathrm{ha}^{-1}\right)\end{array}$}} \\
\hline & & & & \\
\hline 10DAT & 3.39 & 3.36 & 3.18 & 3.75 \\
\hline 25 DAT & 3.67 & 3.32 & 3.60 & 3.69 \\
\hline BPI & 3.90 & 2.97 & 3.79 & 4.02 \\
\hline Control & 2.78 & 2.23 & 2.51 & 2.57 \\
\hline $\operatorname{LSD}(0.05)$ & \multicolumn{4}{|c|}{ NS } \\
\hline $\mathrm{CV}(\%)$ & & & & \\
\hline
\end{tabular}

Table 5. Variation of agronomic efficiency due to interaction of variety and time of USG application

\begin{tabular}{|c|c|c|c|c|c|}
\hline \multirow{3}{*}{$\begin{array}{l}\text { Time of USG } \\
\text { Application }\end{array}$} & \multicolumn{5}{|c|}{ Variety } \\
\hline & \multicolumn{5}{|c|}{ Agronomic efficiency } \\
\hline & Sada mota & Razashail & Kutiagoni & Kalagura & Average \\
\hline 10 DAT & 20.88 & 38.81 & 23.00 & 40.46 & 30.78 \\
\hline 25 DAT & 30.57 & 37.34 & 37.48 & 38.34 & 35.93 \\
\hline BPI & 38.44 & 25.36 & 44.03 & 49.75 & 39.39 \\
\hline Average & 29.96 & 33.84 & 34.84 & 42.85 & \\
\hline LSD (0.05) & & & & & \\
\hline Variety (V) & \multicolumn{5}{|c|}{8.86} \\
\hline Treatments $(\mathrm{T})$ & \multicolumn{5}{|c|}{ NS } \\
\hline $\mathrm{V} \times \mathrm{T}$ & \multicolumn{5}{|c|}{15.36} \\
\hline CV (\%) & \multicolumn{5}{|c|}{25.1} \\
\hline
\end{tabular}

DAT $=$ Days after transplanting, BPI = Before panicle initiation stage, 
Abedin et al.

\section{Partial factor productivity}

The partial factor productivity was the highest with Kalagura variety when USG applied BPI and the lowest from Razashail when USG applied at 10 DAT (Table 6). Matsuo et al. (1995) reported that the partial factor productivity for rice straw is high in the early growth stages and reaches the peak more quickly if more $\mathrm{N}$ is provided. Matsuo et al. (1995) also reported that the extent of nitrogen's contribution to rice yield correspond to the development of the growth pattern of the rice plant.

Table 6. Effect of time of urea super granule application on partial factor productivity of rice.

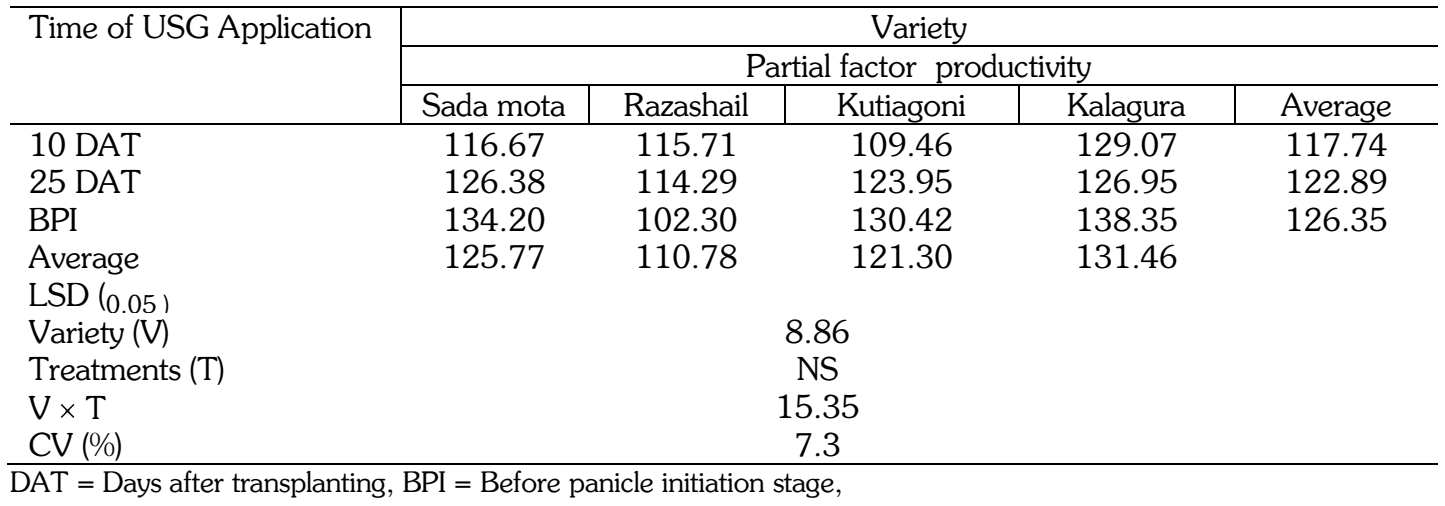

Cost and return from the application of USG at different time

Cost for applying USG was varied from Tk. 4075.0 to Tk. 4425.0 ha $^{-1}$ (Table 7). At the time of USG application during 10DAT, it required 7 labors @ Tk. 350.0 day ${ }^{-1}$ and $65.0 \mathrm{Kg}$ USG @ Tk.25 kg-1 and the total cost was Tk. $4075.0 \mathrm{ha}^{-1}$. At 25DAT and BPI one additional labor was needed. So, the cost was Tk. 4425.0 ha $^{-1}$ during 25DAT and BPI. But there was no cost in control plot for USG application. The highest gross return was obtained from BPI by Tk.73110.0 ha-1followed by 25 DAT and 10 DAT. The lowest gross return Tk. 52660.0 ha $^{-1}$ was found from control plot.Net return of 10DAT, 25DAT and BPI was Tk. 64505.0, Tk. 66965.0 and Tk. 68685.0 ha $^{-1}$, respectively. The highest profit over control was Tk. 16025.0 ha $^{-1}$ from BPI followed by 25 DAT and 10 DAT.

Table 7. Cost and return from the application of USG at different time

\begin{tabular}{|c|c|c|c|c|}
\hline \multirow[t]{2}{*}{ Items } & \multicolumn{4}{|c|}{ Time of USG application } \\
\hline & 10 DAT & 25 DAT & BPI & Control \\
\hline Amount of urea (kg. ha-1) & 65 & 65 & 65 & 0 \\
\hline Cost of urea $\quad\left(T_{k}\right.$ ha $\left.^{-1}\right)$ & 1625.00 & 1625.00 & 1625.00 & 0.00 \\
\hline $\begin{array}{l}\text { Labor needed for fertilizer } \\
\text { application (man-day) }\end{array}$ & 7 & 8 & 8 & 0.00 \\
\hline Labor cost $\quad\left(T k . h^{-1}\right)$ & 2450.00 & 2800.00 & 2800.00 & 0.00 \\
\hline Total cost $\quad\left(\right.$ Tk. ha $\left.{ }^{-1}\right)$ & 4075.00 & 4425.00 & 4425.00 & 0.00 \\
\hline Grain yield (tha-1) & 3.42 & 3.57 & 3.67 & 2.52 \\
\hline Return from yield (Tk. ha-1) & 58140.00 & 60690.00 & 62390.00 & 42840.00 \\
\hline Straw yield $\left(\right.$ tha $\left.^{-1}\right)$ & 5.22 & 5.35 & 5.36 & 4.91 \\
\hline Return from straw $\left(\mathrm{Tk} . \mathrm{ha}^{-1}\right)$ & 10440.00 & 10700.00 & 10720.00 & 9820.00 \\
\hline Gross return (Tk. ha-1) & 68580.00 & 71390.00 & 73110.00 & 52660.00 \\
\hline Net return $\quad\left(T k . h^{-1}\right)$ & 64505.00 & 66965.00 & 68685.00 & 52660.00 \\
\hline Profit over control (Tk. ha-1) & 11845.00 & 14305.00 & 16025.00 & \\
\hline
\end{tabular}


Growth and Yield Performance of Tidal Local Aman Rice by USG

Cost and return from different local aman varieties

Total cost was the same for four varieties that was Tk. $4075.0 \mathrm{ha}^{-1}$. The highest gross return was obtained from Kalagura by Tk. 72870.0 ha $^{-1}$ followed by Sada mota and Kutiagoni (Table 8). The lowest gross return by Tk. $58050.0 \mathrm{ha}^{-1}$ was found from Razashail. Net return of different varieties varied from Tk. $53975.0 \mathrm{ha}^{-1}$ to Tk. $68795.0 \mathrm{ha}^{-1}$. The highest net return was obtained from Kalagura by Tk. 68795.0 ha $^{-1}$ followed by Sada mota and Kutiagoni. The lowest net return by Tk. 53975.0 ha $^{-1}$ was found from Razashail (Table 8). Inspite of the same cost the net return was highest in case of Kalagura because of its higher yield.

Table 8. Cost and return from different local aman vareties

\begin{tabular}{lcccc}
\hline Items & \multicolumn{4}{|c}{ Variety } \\
\cline { 2 - 5 } & Sada mota & Razashail & Kutiagoni & Kalagura \\
\hline Amount of urea (kg. ha-1) & 65 & 65 & 65 & 65 \\
Cost of urea (Tk. ha-1) & 1625.00 & 1625.00 & 1625.00 & 1625.00 \\
Labor needed for fertilizer & 7 & 7 & 7 & 7 \\
application (man-day) & & & & \\
Labor cost (Tk. ha-1) & 2450.00 & 2450.00 & 2450.00 & 2450.00 \\
Total cost (Tk. ha-1) & 4075.00 & 4075.00 & 4075.00 & 4075.00 \\
Grain yield (tha-1) & 3.43 & 2.97 & 3.27 & 3.51 \\
Return from yield (Tk. ha-1) & 58310.00 & 50490.00 & 55590.00 & 59670.00 \\
Straw yield (tha-1) & 5.59 & 3.78 & 4.87 & 6.60 \\
Return from straw (Tk. ha-1) & 11180.00 & 7560.00 & 9740.00 & 13200.00 \\
Gross return (Tk. ha-1) & 69490.00 & 58050.00 & 65330.00 & 72870.00 \\
Net return (Tk. ha ${ }^{-1}$ ) & 65415.00 & 53975.00 & 61255.00 & 68795.00 \\
\hline
\end{tabular}

Cost of urea $=$ Tk. $25.00 \mathrm{~kg}^{-1}$, Labor cost $=$ Tk. 350.00 Man-day ${ }^{-1}$, Paddy price $=$ Tk.17.00 kg-1, Straw price $=$ Tk. $2.00 \mathrm{~kg}^{-1}$.

\section{Selection of $\mathrm{N}$ efficient varieties}

The highest grain yield efficiency index (GYEI) was obtained from the variety Kalagura (Table 9). The GYEI value of Kalagura is 1.10 followed by Sada mota (1.01). The grain yield efficiency index of cultivated varieties Razashail and Kutiagono were 0.80 and 0.99 , respectively.

Table 9. Grain yield efficiency index local aman varieties

\begin{tabular}{l|c|c|c|c|c}
\hline Varieties & $\begin{array}{c}\text { Yield in N } \\
\text { treated plot }\end{array}$ & Average & $\begin{array}{c}\text { Yield in } \\
\text { control plot }\end{array}$ & Average & GYEI \\
\hline Sada mota & 3.65 & 3.55 & 2.50 & 2.52 & 1.01 \\
Razashail & 3.22 & & 2.23 & & 0.80 \\
Kutiagoni & 3.52 & & 2.51 & & 0.99 \\
Kalagura & 3.82 & & 2.57 & & 1.10 \\
\hline
\end{tabular}

GYEI: Grain yield efficiency index

\section{Conclusion}

From the findings of this experiment it may be concluded that the var. Kalagura was found most efficient varieties in respect of yield and nitrogen use efficiency. Application of $\mathrm{N}$ through USG before panicle initial stage increased grain fertility and yield. So, application of USG before panicle initiation stage might be recommended for increased yield and higher net return in cultivating local aman rice varieties. 
Abedin et al.

\section{References}

BRRI (Bangladesh Rice Research Institute). 2004: Annual Report 2003-2004. BRRI, Gazipur-1701. pp. 37-39.

Cassman, K.G., S.K. De Datta, D.C.Olk, J.M. Alcantara, M.I. Samson, J. P. Descalsota and M.A. Dizon.1995. Yield decline and nitrogen economy of long-term experiments on continuous, irrigated rice systems in the tropics. Pages: 181-222 In: Soil Management: Experimental Basis for Sustainability and Environmental Quality. R. Lal and B. A. Stewart, eds. Lewis/CRC: Boca Raton, FL.

Chaturvedi, I. 2005.Effect of nitrogen fertilizers on growth, yield and quality of hybrid rice. J. Central European Agric. 6:611-618.

Fageria, N. K, A. B. Santos and V. C. Baligar. 1997. Phosphorus soil test calibration for lowland rice on an Inceptisol. Agron. J. 89: 737-742.

Fageria, N.K. and V.C. Baligar. 2001. Lowland rice response to nitrogen fertilization. Communications in Soil Science and Plant Analysis. 32:1405-1429.

Fageria, N. K., M. P. Barbosa Filho, L. F. Stone and C. M. Guimaraes. 2004. Phosphorus nutritionof upland rice. In: Phophorus in Brazilian Agriculture, T. Yamada and S. R. S. Abdalla, eds., 401-418. Piracicaba, Sao Paulo, Brazil: Brazilian Potassium and Phosphate Institute.

Hassan, M. S., A. Khair, M. M. Haque, A. K. Azad, A. Hamid. 2009. Genotypic variation in traditional rice varieties for chlorophyll content, SPAD value and nitrogen use efficiency. Bangladesh J. Agril. Res. 34(3): 505-515.

Hossain, M. A., B. C. Roy, S. S. Haque, M. A. I. Khan, A. W. Julfiquar. 2002. Potentiality of hybrid rice in the south central region of Bangladesh. Hybrid rice in Bangladesh, Progress and Future Strategies. Bangladesh Rice Research Institute, pp: 51-52.

Juan, C., W. Zhong, C. Gang and M. Yi-Wei. 2006. Effects of nitrogen fertilizer treatments on filling and respiratory rate of caryopsis in rice. Rice Science. 13: 199-204.

Makino, A. 2011. Photosynthesis, grain yield, and nitrogen utilization in rice and wheat. Plant Physiol. 155: 125-129.

Mnzava, M. M. W. 2002. Nitrogen absorption rate at different growth stages in relation to grain production of lowland rice. Ph D Thesis, Los Banos, Philippines: University of Philippines.

Ranjith, S., T. Dunn, D. Wornes and K. Bechaz. 2008. Timing of nitrogen applications for rice. IREC Farmers' Newsletter, No. 177, Summer 2007-08.

Yoshida, S. 1981. Fundamentals of rice crop science. IRRI, Los Banos. Philippines. p. 269. 